\title{
SANKSI PIDANA TERHADAP PELAKU PENJAMBRETAN MENGAKIBATKAN MATINYA KORBAN
}

\author{
I Putu Bayu Suryadinatha, I Nyoman Gede Sugiartha, Ni Made Sukaryati Karma \\ Fakultas Hukum Universitas Warmadewa, Denpasar-Bali, Indonesia \\ Suryabayu86@yahoo.com, Nyomansugiartha14@gmail.com, Sukariati64@gmail.com
}

\begin{abstract}
Abstrak
Saat ini, diketahui khusunya dikota-kota besar tindak kejahatan sering terjadi seperti penjambretan, pelaku melakukan kejahatan dengan cara merampas paksa barang berharga. Bahkan terjadi penghilangan nyawa jika korban melawan, sehingga pelaku melakukan tindak pembunuhan. Penelitian ini bertujuan untuk mengkaji pengaturan sanksi pidana penjambretan dan mengungkap penerapan sanksi pidana bagi pelaku yang mengakibatkan meninggal akibat penjambretan. Tipe penelitian ini menggunakan metode normatif, dengan pendekatan perundang-undangan, konseptual, kasus. Data yang digunakan adalah bersumber dari data primer dan sekunder. Setelah data terkumpul selanjutnya dianalisis dengan kualitatif deskriptif. Hasil penelitian menunjukkan bahwa Pelaku tindak pidana penjambretan yang mengakibatkan kematian dapat dikenakan pasal 365 ayat (3) sanksinya berupa penjara maksimal 15 tahun. Pengaturan sanksi tindak pidana penjambretan mengacu kepada Pasal 362-367 KUHP karena penjambretan masuk dalam kategori tindak pidana pencurian dengan kekerasan yang mana memenuhi unsur pasal 365 ayat (3) pencurian dengan kekerasan. Penjambretan dikenakan sanksi penjara dan ancaman hukuman terhadap pelaku penjambretan mengakibatkan kematian dikenakan sanksi pidana penjara maksimal 15 tahun. Penjambretan di atur dalam pasal 362 jika tidak dengan kekerasan dan 365 ayat (3) jika dilakukan dengan kekerasan. Untuk penegak hukum sebaiknya penegak hukum menggunakan model Man In The Street dalam memberikan perlindungan terhadap masyarakat.
\end{abstract}

Kata Kunci : Pidana, Penjambretan, Sanksi

\begin{abstract}
Abtract
Increasing crime mugging, crime that commits crime by confiscating valuables. Based on this research, the writer raises the formulation the problem: 1. How regulation mugging criminal sanctions, 2. How imposition criminal sanctions for the perpetrator that results as result mugging. This type research uses the normative method, with an invited-invited, conceptual, case approach. regulation mugging criminal is articles 362-367 of Criminal Code concerning robbery, where mugging regulated in Criminal Code, so crime mugging refers to article 365 paragraph (3) criminal act robbery with violence. Perpetrators mugging which result in death may be subject to Article 365 paragraph (3) with a maximum penalty 15 years in prison. regulation mugging crime based on Articles 362-367 Criminal Code because mugging included in category violent crime which deals with the elements article 365 paragraph (3) robbery with violence. Mugging subject to imprisonment and imprisonment for the mugging subject to a maximum imprisonment of 15 years. Mugging is regulated in article 362 if not with violence and 365 paragraph (3) if it is done with violence. For law enforcers, it is better if law enforcers use the Man In The Street model in providing protection to the community.
\end{abstract}

Keywords: Criminal, Mugging, Sanctions

\section{PENDAHULUAN}

Hukum pidana merupakan keseluruhan mengenai ketentuan-kentuan maupun aturan hukum yang memiliki atau mengandung perintah-perintah dan larangan yang mengharuskan masyarakat atau siapa saja untuk mematuhi atau mentaatinya apabila terdapat masyarakat ataupun seseorang yang melanggar ketentuan atau aturan-aturan hukum itu maka akan diberikannya suatu sanksi maupun hukuman pidana. Dalam hal penerapan sanksi hukum memiliki tujuan untuk keadilan dan kepastian hukum (Sagama, 2016). Setiap orang yang melakukan suatu tindak pidana, apabila seseorang tersebut terbukti melakukannya patut dikenakan hukuman sesuai dengan pasal yang seseorang tersebut langgar. Hukum memiliki fungsi mengatur hubungan antara manusia satu dengan lainnya dan Negara agar segala sesuatu berjalan secara tertib sesuai dengan ketentuan aturan-aturan hukum yang berlaku demi terwujudnya kedamaian dalam kehidupan bermasyarakat (Lathif, 2017).

Berbagai kejahatan yang ada dimasyarakat dapat dikategorikan sebagai kejahatan umum maupun kejahatan khusus. Walaupun dari segi prakteknya tidaklah jarang pula adanya tumpang tindih 
pada ketentuan-ketentuan yang mengatur dari kejahatan yang dilakukan tersebut. Misalnya, dilihat dari adanya kejahatan korupsi kejahatan ekonomi maupun kejahatan subversi. Dilihat dari dikategorikannya kejahatan-kejahatan yang ada, kejahatan umum terdiri dari berbagai macam-macam bentuk, salah satunya adalah kejahatan pencurian. Dari berbagai macam bentuk kejahatan umum yang dimana didalamnnya terdapat kejahatan pencurian dalam hal ini kejahatan pencurian dilihat dari kuhp (kitab undang-undang hukum pidana) dapat dibagi menjadi beberapa macam kejahatan pencurian, yang dimana dalam kuhp kejahatan pencurian diatur dari pasal 362 sampai dengan 367 kuhp. Sesuai dengan pengaturannya pada ketentuan pasal 362 kuhp maupun mengenai pencurian biasa. Dalam hal mengenai kejahatan pencurian dengan pemberatan sesuai dengan ketentuannya yang diatur dalam pasal 363 KUHP, kejahatan pencurian ringan pengaturannya diatur dalam pasal 364 kuhp, kejahatan pencurian dengan kekerasan ketentuannya diatur dalam pasal $365 \mathrm{kuhp}$, serta mengenai pencurian dalam keluarga yang ketentuannya diatur dalam pasal 367 pencurian dalam keluarga. Mengenai adanya pengaturan kejahatan pencurian dengan kekerasan ditambah dengan kejahatan pencurian dengan pemberatan sesuai dengan pasal yang mengatur kejahatan pencurian tersebut dimasukkan kedalam gequalificeerde diefstal atau pencurian yang dikualifikasikan oleh akibatnya.

Kejahatan pencurian yang terjadi selama ini yang semakin meningkat maka berkembang juga adanya bentuk-bentuk lain dari kejahatan pencurian itu sendiri, salah satunya kejahatan penjambretan merupakan perbuatan maupun tindakan negatif dengan merampas harta benda berharga milik orang lain secara paksa yang mengakibatkan adanya kerugian terhadap korbannya. Dalam hal ini dapat dikatakan pelaku kejahatan penjambretan melakukan aksi maupun tindakan kejahatan dengan cara menarik ataupun merampas secara paksa barang berharga yang ada dalam penguasaan penuh dari korbannya dengan adanya maksud untuk mempermudah maupun menyiapkan sipelaku untuk melakukan pencurian tersebut dan apabila penjambretan yang dilakukan pelaku gagal (tertangkap tangan) si pelaku masih memiliki kesempatan untuk melarikan diri.

Di Indonesia sering terjadinya kejahatan pencurian dengan kekerasan dalam hal ini dapat dikatakan mengenai kasus kejahatan penjambretan yang dimana biasanya sipelaku menggunakan sepeda motor dalam aksi kejahatan tersebut. Dalam aksi kejahatan yang dilakukan pelaku dapat pula mengakibatkan korbannya mengalami luka-luka bahkan sampai meninggal dunia. Mengenai kasus kejahatan penjambretan biasanya si pelaku menargetkan atau mengincar para korbannya yang dominan sedang mengendarai kendaraan roda dua (motor) yang memakai tas selempang yang mana dominan target si pelaku seorang perempuan. Mengenai kejahatan pencurian yang khususnya dalam hal ini kejahatan penjambretan sesuai dengan ketentuan dan pengaturan hukum di Indonesia dalam hukum acara materiil yang dimana mengatur mengenai peraturan hukum pidana yang apabila seseorang melakukan suatu pelanggaran-pelanggaran maupun kejahatan-kejahatan yang melanggar sesuai dengan ketentuan hukum pidana dapat dijatuhi dengan adanya sanksi hukum sesuai dengan pelanggaran maupun kejahatan yang dilakukannya sedangkan terdapat juga hukum acara formil yang sebagaimana mengatur mengenai penerapan atau proses hukum yang berlaku dalam proses peradilan pidana (Hamzah, 1983).

Peranan hukum masyarakat adalah melindungi, mengayomi serta memberi jaminan akan kesejahteraan, artinya dengan keberadaan hukum, maka kehidupan masyarakat baik dalam berperilaku,berkeluarga,bermasyarakat, berbangsa dan bernegara serta berinternasional menjadi baik, teratur dan benar serta tertib dan aman (Rasyidi, 2018) \& (Hutahaean, 2013). Dari uraian sebelumnya, maka penelitian ini mengkaji pengaturan sanksi pidana penjambretan dan mengungkap penerapan sanksi pidana bagi pelaku yang mengakibatkan meninggal akibat penjambretan

\section{METODE PENELITIAN}

Tipe penelitian ini menggunakan metode hukum yang bersifat normatif dengan pendekatan Perundang-undangan, pendekatan konseptual, dan pendekatan kasus. Pendekatan perundangundangan adalah pendekatan dilakukan dengan Undang-undang dan regulasi yang bersangkut paut dengan isu hukum yang sedang ditangani. Pendekatan konseptual beranjak dari pandangan-pandangan dang doktrin-doktrin yang berkembang didalam ilmu hukum penelitian akan menemukan ide-ide yang melahirkan pengertian, serta konsep-konsep hukum dengan isu yang di hadapi. Sedangkan pendekatan kasus merupakan pendekatan yang dilakukan dengan meneliti maupun menganalisa suatu kasus yang dipakai. Adapun sumber bahan hukum yang digunakan dalam penilitian ini yaitu bahan hukum primer dan bahan hukum sekunder. Sedangkan teknik pengumpulan bahan hukum dilakukan dengan cara 
diperolehnya dari bahan-bahan hukum kepustakaan dengan cara mengumpulkan membaca dan mencatat bahan-bahan hukum yang didapat yang berhubungan dengan penelitian yang penulis buat yang mengenai sanksi pidana terhadap pelaku penjambretan yang mengakibatkan matinya korban. Selanjutnya setelah data terkumpul diolah dan diaanalisis secara kualitatif deskriptif (Sugiyono, 2005)

\section{HASIL DAN PEMBAHASAN}

\section{Pengaturan Sanksi Pidana Penjambretan}

Dalam ketentuan hukum positif di Indonesia dari beberapa jenis sanksi yang ada, jenis sanksi yang paling dominan dipergunakan adalah sanksi pidana, dalam menjatuhkan hukuman terhadap seseorang yang dinyatakan bersalah melakukan suatu perbuatan pidana maupun tindakan-tindakan melawan hukum. Dilihat dari pengertiannya sanksi pidana dapat dikatakan sebagai penderitaan maupun nestapa yang diberikan kepada orang yang melakukan perbuatan maupun tindakan-tindakan yang memiliki unsur-unsur syarat tertentu dalam konteks perbutan pidana (Andrisman, 2009). Lebih jelasnya sanksi pidana diartikan sebagai hukuman yang diberikan kepada orang yang terbukti melakukan tindakan, pelanggaran-pelanggaran, maupun kekeliruan yang menyebabkan ketidaknyamanan dan ketidakketentraman masyarakat ataupun merupakan suatu sanksi yang harus diterapkan terhadap setiap suatu perbuatan pidana sebagaimana akibat dari perbuatan yang diperbuat si pelaku agar si pelaku merasakan efek jera dan tidak mengulangi perbuatan-perbuatannya tersebut. Maka dalam hal ini sesuai dengan pengertian dari sanksi pidana maka sanksi pidana memiliki tujuan retributive atau dapat dikatakan sebagai suatu tindakan pencegahan terhadap tindakan-tindakan yang melanggar aturan-aturan hukum yang berlaku.

Mengenai perumusannya didalam peraturan perundang-undangan pada hakekatnya mengenai penjelasan sistem pemidanaan merupakan suatu sistem dan merupakan bagian dari mekanisme penegakan hukum pidana yang memiliki wewenang menjatuhkan pidana maupun dapat mengatur hak masyarakat pada umumnya. Dilihat dari hukum positif di Indonesia terdapat jenis-jenis pemidanaan yang pengaturannya diatur dalam KUHP pada pasal 10, yang diantaranya menyebutkan adanya pidana pokok dan pidana tambahan. Dalam hal ini mengenai pidana pokok memiliki sifat fakultatif yang memiliki arti dapat dijatuhi ataupun tidaknya hukuman atau sanksi terhadap si pelaku. Pada umumnya tujuan dari adanya penerapan suatu sanksi pidana terhadap pelaku tindak kejahatan bertujuan untuk suatu upaya pembinaan moralitas dan etika serta memberikan suatu efek jera bagi si pelaku tindak pidana atau kejahatan yang nantinya diharapkan agar si pelaku tidak mengulangi perbuatannya tersebut (Suparni, 1996).

Mengenai pengaturan sanksi pidana terhadap pelaku tindak pidana penjambretan ketentuan pengaturannya mengacu pada buku kedua mengenai kejahatan pada bab XXII (22) dalam pasal 362 sampai dengan pasal 367 KUHP yang dimana ketentuan pasal tersebut mengatur mengenai tindak pidana pencurian, dikarenakan mengenai tindak pidana penjambretan (kata penjambretan) tidak disebutkan/ tidak diatur dalam KUHP maka dari itu sesuai dengan unsur-unsurnya kejahatan tau tindak pidana penjambretan ketentuan unsur-unsurnya masuk dalam kategori tindak pidana pencurian dengan kekerasan. Kata kekerasan dalam hal ini dimaksudkan termasuk didalamnya mengikat maupun menyekap orang atau korban pemilik rumah/ yang ada didalam kamar. Kekerasan tersebut haruslah dilakukan terhadap korbannya dan bukan terhadap barangnya, dan dilakukan sebelumnya, bersama-sama atau setelah pencurian yang dilakukan memiliki maksud memudahkan perbuatan tersebut apabila tindakan kejahatan yang dilakukan itu gagal (tertangkap tangan) maka masih berkesempatan bagi si pelaku maupun kawan si pelaku yang turut ikut melakukan aksi kejahatan tersebut dapat melarikan diri ataupun agar barang yang dicuri si pelaku tetap berada ditangan si pelaku (R, 1991).

\section{Sanksi Pidana Terhadap Pelaku Penjambretan yang Mengakibatkan Matinya Korban}

Kejahatan penjambretan merupakan suatu penyimpangan sosial yang berdampak merugikan banyak orang atau kalayak banyak yang biasanya kejahatan ini dilakukan oleh dua orang, yang dilakukan malam hari dan jalanan yang sudah sepi. Biasanya di pelaku membawa sajam (senjata tajam) dan tindakan yang dilakukan pelaku tidak segan-segan dapat melukai korbannya apabila saat si pelaku melakukan aksi kejahatan terhadap korban dan korbannya melawan. Dari adanya kejahatan penjambretan dapat menimbulkan suatu tindak pidana yang dimana si pelaku merampas harta milik korbannya secara paksa dengan melakukan suatu tindak kekerasan guna memperlancar aksi kejahatan si pelaku. Dapat dikatakan kejahatan penjambretan merupakan suatu perbuatan yang dianggap 
melawan hukum atau ketentuan peraturan hukum yang berlaku sebagai mana dapat dilihat dari unsurunsur perbuatannya lebih condong bersifat negatif dan merugikan (RM, 1994). Dimana perbuatan tersebut dilakukannya yang bersifat memaksa untuk menjarah atau mengambil barang yang merupakan hak dari orang lain (korban) yang bukan miliknya (si pelaku) yang dapat menimbulkan atau adanya kerugian materiil dari pihak korban.

Sanksi pidana merupakan jenis sanksi yang paling umum (banyak) dipergunakan dalam hal memberikan ancaman ataupun menjatuhkan hukuman bagi seseorang atau para pelaku yang dinyatakan bersalah melakukan perbuatan pidana (Suhariyono AR, 2009). Agar seseorang dapat dinyatakan telah terbukti melakukan suatu tindak pidana pencurian maka orang tersebut haruslah memenuhi semua unsur yang tercantum pada ketentuan pengaturan yang berlaku baik itu unsur objektif maupun unsur subjektif. Mengenai pengenaan sanksi pidana terhadap pelaku tindak pidana penjambretan, tindak pidana penjmabretan tergolong atau dapat dikategorikan sebagai kejahatan pencurian dengan kekerasan karena para pelaku kejahatan penjambretan mengambil barang dari korbannya dengan melakukan atau disertai dengan kekerasan guna mempermudah aksi pencurian atau memungkinkannya si pelaku kejahatan untuk melarikan diri, Sesuai dengan penegasan pengaturannya dalam pasal 365 KUHP pada ayat (1) dapat dijatuhi hukuman pidana penjara paling lama Sembilan tahun dan apabila perbuatan kejahatan tersebut dilakukan pada waktu malam hari pada sebuah rumah, jalan umum, transportasi umum dan apabila perbuatan kejahatan yang dilakukan sebanyak dua orang atau lebih pelaku, kemudian perbuatan kejahatan tersebut dilakukan atau disertai dengan merusak ataupun mengakibatkan luka-luka berat terhadap korbannya sesuai dengan penganturannya dalam pasal 365 ayat (2) dijatuhi sanksi pidana berupa sanksi penjara paling lama dua belas tahun hukuman penjara. Apabila perbuatan kejahatan tersebut menimbulkan atau mengakibatkan kematian dari korbannya maka sesuai dengan pengaturannya pada ayat (3) dijatuhi hukuman penjara paling lama lima belas tahun. Merujuk pada penjelasan diatas mengenai tindak pidana penjambretan yang mengakibatkan matinya korban. Walaupun tindak pidana penjambretan (kata penjambretan) tidak disebutkan dalam KUHP, mengenai pengenaan sanksi bagi para pelaku penjambretan masih dapat dijatuhi hukuman. Hal ini sesuai dengan dilihatnya atau dikaitkannya dari pengaturannya dalam pasal 365 ayat (3) KUHP buku kedua tentang kejahatan bab XXII mengenai pencurian.

Merujuk dari pasal 362 tentang pencurian dan 365 ayat (3) terhadap tindak pidana pencurian dengan kekerasan (penjambretan) yang mengakibatkan kematian baik itu dilakukan dengan sengaja ataupun tidak disengaja dapat dikenakan sanksi pidana penjara dengan ancaman paling lama lima belas tahun. Pengenaan sanksi pidana terhadap tindak pidana penjambretan dikenakan pasal 365 ayat (3) KUHP pencurian dengan kekerasan yang mengakibatkan matinya korban dikenakan pasal 365 ayat (3) yaitu dari masing-masing pasal dikenakan sanksi pidana penjara, dimana penjara merupakan jenis pidana yang paling banyak diancamkan kepada pelaku tindak pidana dalam Buku II KUHP. Dalam tindak pidana penjambretan yang didahului dengan kekerasan yang mengakibatkan kematian dikenakan pasal 365 ayat (3) dengan ancaman pidana penjara maksimal 15 tahun penjara. Karena penjambretan tersebut aturannya tidak berdiri sendiri dalam KUHP tetapi terhadap tindak pidana penjambretan ini memenuhi unsur-unsur terhadap tindak pidana pencurian dengan kekerasan yang nantinya dapat di kenakan sanksi sesuai pasal tersebut.

\section{SIMPULAN DAN SARAN}

\section{Simpulan}

Berdasarkan uraian di atas, maka dapat disimpulkan bahwa Tindak pidana penjambretan diatur dalam pasal 362 KUHP tentang pencurian biasa hingga pasal 367 pencurian dalam keluarga, karena penjambretan masuk dalam kategori pencurian dengan kekerasan maka dari itu penjambretan yang mengakibatkan korban mati mengacu pada pasal 365 ayat (3) KUHP yang berbunyi: " jika perbuatan mengakibatkan kematian, maka diancam dengan pidana paling lama lima belas tahun" dikarenakan pengertian penjambretan memiliki unsur yang sama dengan tindak pidana pencurian dengan kekerasan. Pengenaan sanksi terhadap terhadap pelaku penjambretan yang mengakibatkan matinya korban diatur pada pasal yaitu pasal 365 ayat (3) tentang pencurian dengan kekerasan yang mengakibatkan korban mati, pasal tersebut dijatuhkan sanksi pidana penjara terhadap pelaku (deader) dimana unsur-unsur tindak pidana penjambretan yang harus di penuhi sebelum menjatuhkan sanksi pidana adalah barang siapa mengambil barang sesuatu barang kepunyaan orang lain dengan maksud untuk dimiliki secara melawan hukum. Dalam tindak pidana penjambretan yang mengakibatkan 
korban mati pelaku dapat di kenakan pasal 365 ayat (3) mengenai pencurian dengan kekerasan yang ancaman hukumannya diancam pidana paling lama lima belas tahun penjara.

\section{Saran}

Berdasarkan hasil penelitian di atas, adapun saran yang diberikan yaitu sebaiknya penegak hukum menggunakan model Man In The Street di dalam memberikan perlindungan terhadap masyarakat dan tidak hanya memperkuat sanksi saja sebagai efek jera bagi pelaku. Terhadap masyarakat agar tidak keluar pada malam hari dan tidak menggunakan barang-barang berharga yang mengundang pelaku penjambretan melakukan aksinya. Masyarakat sebaiknya lebih waspada ketika malam hari karena kejahatan penjambretan dapat terjadi dimana saja dan tidak pandang bulu. Penanggulangan kejahatan penjambretan bukan hanya menjadi tugas kepolisian untuk mengawasi tapi seluruh masyarakat diharapkan mampu berpartisipasi dalam mencegah dan menanggulangi kejahatan penjambretan di dalam masyarakat itu sendiri, serta meningkatkan kerjasama antara masyarakat aparat kepolisian dalam menanggulangi kejahatan penjambretan tersebut.

\section{DAFTAR PUSTAKA}

Andrisman, T. (2009). Hukum Pidana. Lampung. Universitas.

Hamzah, A. (1983). Pengantar Hukum Acara Pidana. Jakart. Ghalia Indonesia.

Hutahaean, B. (2013). Penerapan Sanksi Pidana bagi Pelaku Tindak Pidana Anak. Jurnal Yudisial, $6(1), 64-79$.

Lathif, N. (2017). Teori Hukum Sebagai Sarana Alat untuk Memperbaharui atau Merekayasa Masyarakat. Jurnal Law Review, 3(1), 73-94.

R, S. (1991). Kitab Undang-Undang Hukum PIdana (KUHP) Serta Komentar-Komentarnya Lengkap Pasal Demi Pasal. Bogor. Politeia.

Rasyidi, M. A. (2018). Fungsi Hukum di Dalam Masyarakat dan Peranan Hukum Bisnis di Indonesia. Jurnal Ilmiah Hukum Dirgantara, 9(1), 106-116.

RM, S. (1994). Penuntutan dalam Praktek Peradilan. Jakarta. Sinar Grafika.

Sagama, S. (2016). Analisis Konsep Keadilan, Kepastian Hukum dan Kemanfaatan dalam Pengelolaan Lingkungan. Mazahib, 15(1), 20-41.

Sugiyono. (2005). MemahamiPenelitian Kualitatif. Bandung: Alfabeta.

Suhariyono AR. (2009). Penentuan Sanksi Pidana dalam Satu Undang-undang. Legislasi Indonesia, $6(4), 7-8$.

Suparni, N. (1996). Eksistensi Pidana Denda dalam Sistem Pidana dan Pemidanaan. Jakarta. Sinar Grafika. 